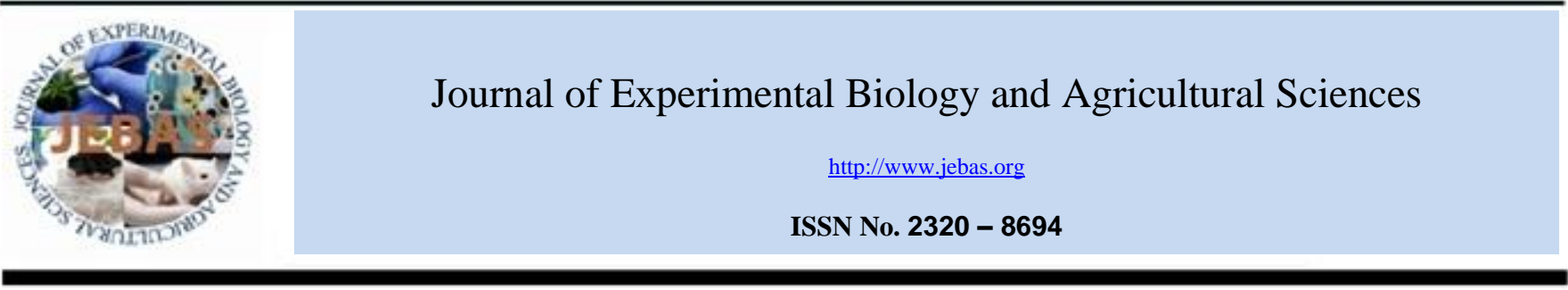

\title{
EFFECTS OF INTEGRATED MANAGEMENT OF BIO AND CHEMICAL FERTILIZERS ON YIELD OF MAIZE HYBRIDS (Zea mays L.)
}

\section{Fatemeh Nouraki ${ }^{1}$, Mojtaba AlaviFazel $^{2, *}$, Ahmad Naderi $^{3}$, EbrahimPanahpoor $^{4}$ and ShahramLak $^{5}$}

${ }^{1}$ Department of Agronomy, Khuzestan Science and Research Branch, Islamic Azad University, Ahvaz, Iran

${ }^{2}$ Department of Agronomy, Ahvaz Branch, Islamic Azad University, Ahvaz, Iran

${ }^{3}$ Faculty of Agriculture and Natural Resources Research Center of Khuzestan, Ahvaz, Iran

${ }^{4}$ Department of Soil Science, Ahvaz Branch, Islamic Azad University, Ahvaz, Iran

${ }^{5}$ Department of Agronomy, Ahvaz Branch, Islamic Azad University, Ahvaz, Iran

Received - April 18, 2016; Revision - May 04, 2016; Accepted - June 28, 2016

Available Online - June 30, 2016

DOI: http://dx.doi.org/10.18006/2016.4(4).421.426

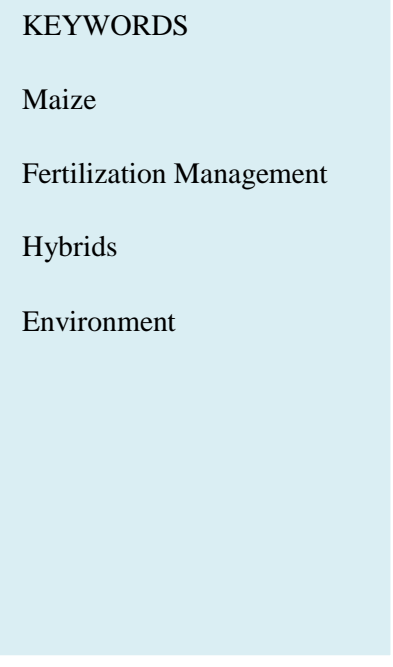

\begin{abstract}
Fertilizer management plays an important role in obtaining satisfactory yields from maize. In addition, fertilizer management is essential for achieving sustainable agriculture and protecting the environment. The reported experiment was conducted in the summers of 2013-2014 in the Aghili region in the north of Khuzestan Province. The experiment was conducted as four replicates using split plots randomized complete block design (RCBD). The experiments consisted of four levels $(25,50,75$, and $100 \%)$ of chemical fertilizers nitrogen (urea) and phosphorus (Triple superphosphate) and level of bio fertilizers (Control and $100 \%$ ), which were the main factors. The sub factor was three types of maize hybrids, which were single cross 704, single cross 701(SLD45/1/2-1× MO17), and single cross Mobin (SLD 45/1/2-1× SLH 2/29/14/2-4/1). The highest yields were obtained from the single cross 704 with $25 \%$ chemical and $100 \%$ bio-fertilizers $(12,875 \mathrm{~kg} / \mathrm{ha})$ and it was followed by single cross 704 with $50 \%$ chemical and $100 \%$ bio-fertilizers $(12,385 \mathrm{~kg} / \mathrm{ha})$, while the lowest yield was obtained from the single cross Mobin with $25 \%$ chemical and $100 \%$ bio fertilizers $(10,215 \mathrm{~kg} / \mathrm{ha})$. The yield and component yield differences were observed between treatments so that the grain yield and biological yield as well as number of grains per row were significant at the $1 \%$ level and there were no significant differences between the other components.
\end{abstract}

* Corresponding author

E-mail: Mojtaba_alavifazel@yahoo.com (Mojtaba AlaviFazel)

Peer review under responsibility of Journal of Experimental Biology and Agricultural Sciences.

Production and Hosting by Horizon Publisher India [HPI] (http://www.horizonpublisherindia.in/).

All rights reserved.
All the article published by Journal of Experimental Biology and Agricultural Sciences is licensed under a Creative Commons Attribution-NonCommercial 4.0 International License Based on a work at www.jebas.org.

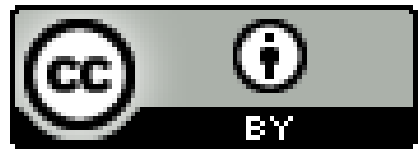




\section{Introduction}

Maize (Zea mays L.) is an important cereal crop in Iran, and it ranks third in worldwide production after wheat and rice (Kusaksiz, 2010). It is grown for fodder as well as for grain in Iran. Approximately 320,000 hectares of field corn were grown with a production of $2,560,000$ tons at an average grain yield of $8,000 \mathrm{~kg} / \mathrm{ha}$ in Iran in 2012 (Rahmany \& Nouraki, 2015). Nitrogen is a basic component that played a decisive role in the intensification of plant production (Scharf, 2002). It is the most critical element for plant growth and plays a key role in many metabolic and physiological functions (Balasubramaniyan \& Palaniappan, 2001).The levels of the application of nitrogen and phosphorus, the location, and the variety all have effects on the final yield of corn. Previous work has indicated that there is a significant response to the application of nitrogen fertilizers in the yields obtained from maize (Bundy \& Carter, 1988). The main factor that limits growth and grain filling is the availability of nitrogen (El-Douby et al., 2001; Zeidan et al., 2006). Chemical fertilizers are needed to supplement the nutrients in the soil. Heavy doses of chemical fertilizers and pesticides are commonly used to enhance corn yields. A low nitrogen content in the soil leads to poor absorption of micronutrients by plants, which may be insufficient for the complete development of the plant tissue (Szulc, 2013). On the other hand, an excessive accumulation of mineral nitrogen in the soil poses a risk of water pollution as a result of nitrate leaching by precipitation (Ladha et al., 2005). Organic manure is cheap and could be used as a substitute for chemical fertilizers (Delate \& Camberdella, 2004). The application of bio fertilizers has become of great necessity to get a yield of sufficient high quality and to avoid environmental pollution (Shevananda, 2008).Biological fertilizers are obviously an important part of a sustainable agricultural system and have an important role in crop production by maintaining soil fertility (Chen, 2006). According to Zeid (2008), a compound organic fertilizer and urea or a combination of urea and polyamines significantly enhanced yield, growth, and the chlorophyll index.

The use of renewable resources and inputs is one of the fundamental principles of sustainable agriculture that enables maximum crop productivity and minimal environmental risk (Kizilkaya 2008). At present in Iran, diverse maize genotypes i.e., single cross and double cross hybrids, synthetics, and composites, are being grown. These genotypes respond differently to various agro management practices, especially plant density and nutrition management. There are many factors responsible for lower grain yield in many different countries, including Iran, but fertilizer management plays an important role for obtaining satisfactory yields and to increase crop productivity. Nutrient management may be achieved by the involvement of organic sources, bio-fertilizers, and micronutrients (Singh et al., 2002). According to the Mohammed et al. (2001), the use of bio-fertilizers offers agronomic and environmental benefits to intensive farming systems in Egypt, and the data showed that using Azospirillum brasilense or commercial bio fertilizers in cereals with a half $\mathrm{N}$ rate $(144 \mathrm{kgN} / \mathrm{ha})$ caused a significant increase in yield. Further, seed inoculation with Rhizobium, phosphorus solubilizing bacteria, and organic amendment increased the seed production of the crop (Panwar et al., 2006). Therefore, the present study was conducted to evaluate the effects of individual or combined application of chemical and biological fertilizers on the yield and yield components of three types of maize hybrids.

\section{Materials and Methods}

The experiment was conducted in the cropping season of 20132014 at the Aghili region in the north of Khuzestan Province of Iran. Soil has been tested by the laboratory that the physical and chemical properties of the study area soil can be seen in table 1.The experiment was laid out in a split plot with a randomized complete block design (RCBD) with four replications. The treatments included four levels $(25,50,75$, and $100 \%$ the recommended amount) of chemical fertilizer application and level (Control and 100\%) of bio fertilizer application, which were the main factors. The sub factor was three types of maize hybrids viz single cross 704 , single cross 701(SLD45/1/2-1× MO17), and single cross Mobin (SLD $45 / 1 / 2-1 \times$ SLH 2/29/14/2-4/1). The plots were prepared for the maize to be planted by plowing, fertilizing, and leveling. The size of each plot was $6 \times 5 \mathrm{~m}^{2}$ and each block has 12 treatments. For the experiment, the distance between rows to rows was 75 $\mathrm{cm}$ with six rows per treatment, and irrigation was applied when the plants required it. The main factor had four levels related to the chemical and bio-fertilizers applied while there were three levels representing the maize hybrids for the sub factor. The applications of the chemical fertilizers were made up of urea, triple superphosphate, and potassium sulphate at levels of $46 \%, 46 \%$, and $50 \%$ respectively, while nitroxin (Azospirillum sp., Pseudomonas sp., and Azotobacter sp.) and biosuperphosphate microbial (including Baccilus caogulans) were the bio-fertilizers that were applied in the form of seed inoculation and fertilization. The bio-fertilizers were applied together with the irrigation water at the eight leaf stage.

Table 1Soil's chemical and physical properties

\begin{tabular}{|l|cccccccc|c|}
\hline Depth & $\begin{array}{c}\text { EC } \\
(\mathrm{Ms} / \mathrm{cm})\end{array}$ & PH & OC (\%) & ppm) $(\mathrm{P}$ & $\mathrm{ppm})(\mathrm{K}$ & Clay (\%) & Sand (\%) & Silt $(\%)||$ & Texture \\
\hline $0-30$ & 4.07 & 8.46 & 0.507 & 8 & 180 & 24 & 34 & 42 & Loam \\
\hline $30-60$ & 2.69 & 8.5 & 0.351 & 7 & 170 & 24 & 34 & 42 & Loam \\
\hline
\end{tabular}


Table 2 Results of ANOVA of component yield and maize yield.

\begin{tabular}{|c|c|c|c|c|c|c|c|}
\hline Source of variance & df & $\begin{array}{c}1000 \text { - grain } \\
\text { weight }\end{array}$ & $\begin{array}{c}\text { Number of grains } \\
\text { per row }\end{array}$ & $\begin{array}{l}\text { Number of } \\
\text { rowsper ear }\end{array}$ & $\begin{array}{l}\text { Grain } \\
\text { yield }\end{array}$ & $\begin{array}{l}\text { Biological } \\
\text { yield }\end{array}$ & $\begin{array}{c}\text { Harvest } \\
\text { index }\end{array}$ \\
\hline Year & 1 & $113800^{* *}$ & $3661.97^{* * *}$ & $7.0313^{*}$ & $112.575^{*}$ & $736.160^{* * *}$ & $467.67^{*}$ \\
\hline Block(year) & 6 & $4196^{\text {ns }}$ & $44.67^{\mathrm{ns}}$ & $0.6967^{\mathrm{ns}}$ & $17.190^{*}$ & $42.642^{*}$ & $84.69^{\text {ns }}$ \\
\hline Fertilization & 3 & $654^{\mathrm{ns}}$ & $3.93^{\text {ns }}$ & $3.1346^{\mathrm{ns}}$ & $3.822^{\mathrm{ns}}$ & $31.145^{*}$ & $43.58^{\mathrm{ns}}$ \\
\hline Year $\times$ Fertilization & 3 & $4486^{\mathrm{ns}}$ & $55.42^{\mathrm{ns}}$ & $0.7089^{\text {ns }}$ & $6.512^{\mathrm{ns}}$ & $21.916^{\mathrm{ns}}$ & $89.98^{\text {ns }}$ \\
\hline Error & 18 & 1481 & 24.22 & 1.3774 & 3.515 & 10.145 & 52.15 \\
\hline Hybrid & 2 & $18059^{* *}$ & $1219.97^{* * *}$ & $25.8256^{* *}$ & $47.742^{\text {** }}$ & $58.628^{*}$ & $204.27^{\prime \prime}$ \\
\hline Year $\times$ Hybrid & 2 & $2003^{\text {ns }}$ & $99.56^{* *}$ & $0.7181^{\mathrm{ns}}$ & $15.210^{*}$ & $94.983^{* *}$ & $215.53^{\prime \prime}$ \\
\hline Fertilization $\times$ Hybrid & 6 & $1296^{\mathrm{ns}}$ & $20.88^{\mathrm{ns}}$ & $1.0911^{\mathrm{ns}}$ & $6.028^{\mathrm{ns}}$ & $7.466^{\mathrm{ns}}$ & $142.86^{\prime \prime}$ \\
\hline $\begin{array}{l}\text { Fertilization } \times \\
\text { Hybrid } \times \text { Year }\end{array}$ & 6 & $3828^{* *}$ & $58.91^{*}$ & $0.6745^{\mathrm{ns}}$ & $7.632^{\mathrm{ns}}$ & $20.688^{*}$ & $83.42^{\mathrm{ns}}$ \\
\hline Error & 48 & 285.02 & 3.8654 & 0.4329 & 0.8297 & 2.18 & 15.49 \\
\hline C.V (\%) & - & 6.11 & 3.91 & 3.38 & 7.11 & 6.25 & 8.02 \\
\hline
\end{tabular}

Ns represents to Not-significant, $* *=$ significant at $0.01 \%$ and $*$ significant at $0.05 \%$

To record the grain and biological yield data, the two central rows in each treatment were harvested, sun dried, then dried in an oven with a temperature of $70^{\circ} \mathrm{C}$ for 48 hours, and weighed. Harvest index was calculated by the following formula. The recorded data were statistically analyzed using the Minitab 14, MSTAT-C version 2.10 software. The purpose of the analysis of variance was to determine the significant effect of the treatments on the corn. Dancan's tests were used at 5\% level for the average separation of the parameters.

Harvest index $=$ grain yield/biological yield $\times 100$

\section{Results and discussion}

\subsection{Grain Yield (kgha-1)}

The analysis of variance showed that the two years of testing in terms of grain yield at the 5\% level were statistically significant (table2).The difference in the combination of chemical fertilizer, biological fertilizer, and yield remained significant, but according to table $350 \%$ chemical fertilizer with $100 \%$ bio-fertilizer gave $11,715 \mathrm{Kg} / \mathrm{ha}$ grain yield, which was the highest while the $100 \%$ chemical fertilizer alone gave the amount of $11,165 \mathrm{~kg} / \mathrm{ha}$, which was the lowest yield. The results of the interaction of bio and chemical fertilizer applications on the hybrids' yield and yield components are shown in table 4 . The bio-fertilizer with $\mathrm{H}_{1} \mathrm{~F}_{4}$ treatment resulted in the maximum yield of $12,875 \mathrm{~kg} / \mathrm{ha}$, while the $50 \%$ chemical fertilizer with $100 \%$ biological fertilizer from $\mathrm{H}_{1} \mathrm{~F}_{3}$ gave the second greatest yield of $12,385 \mathrm{~kg} / \mathrm{ha}$. It has been reported that the amount of chemical fertilizer can be reduced by $50 \%$ when a phosphate soluble and growth promoting bacteria are applied to corn without reducing the yield (Yazdani et al., 2009). Other studies determined that plant growth was improved even when the nitrogen fertilizer applied was reduced by $30-35 \%$ as long as the seeds had been inoculated with growth promoting bacteria. An increase in the biomass of the microbial community was related to the soil health as this had an effect on the balance and availability of nutrients in the rhizosphere of the roots that lead to a higher yield (Boddey \& Dobereiner, 1988; El-kholy et al., 2005; Biari et al., 2008)

Table 3 Effect of individual application of chemical and biofertilizers on various growth parameters of the corn plants.

\begin{tabular}{|lcccccc|}
\hline Treatments & $\begin{array}{c}\mathbf{1 0 0 0} \text { - grain } \\
\text { weight }(\mathbf{g})\end{array}$ & $\begin{array}{c}\text { Number of grains } \\
\text { per row }\end{array}$ & $\begin{array}{c}\text { Number of row } \\
\text { per ear }\end{array}$ & $\begin{array}{c}\text { Grain yield } \\
(\mathbf{k g h a -})\end{array}$ & $\begin{array}{c}\text { Biological yield } \\
\left(\mathbf{k g h a}-\mathbf{-}^{-}\right)\end{array}$ & $\begin{array}{c}\text { Harvest index } \\
(\%)\end{array}$ \\
\hline $\mathbf{F}_{\mathbf{1}}(\mathbf{c o n t r o l})$ & $330.95^{\mathrm{b}}$ & $32.69^{\mathrm{a}}$ & $14.18^{\mathrm{a}}$ & $11165^{\mathrm{d}}$ & $19580^{\mathrm{d}}$ & $57.37^{\mathrm{a}}$ \\
\hline $\mathbf{F}_{\mathbf{2}}$ & $330.25^{\mathrm{b}}$ & $32.68^{\mathrm{a}}$ & $14.17^{\mathrm{a}}$ & $11230^{\mathrm{c}}$ & $19720^{\mathrm{c}}$ & $57.4^{\mathrm{a}}$ \\
\hline $\mathbf{F}_{3}$ & $336.55^{\mathrm{a}}$ & $32.82^{\mathrm{a}}$ & $14.63^{\mathrm{a}}$ & $11715^{\mathrm{a}}$ & $21075^{\mathrm{a}}$ & $56.18^{\mathrm{a}}$ \\
\hline $\mathbf{F}_{\mathbf{4}}$ & $332.70^{\mathrm{b}}$ & $32.34^{\mathrm{a}}$ & $14.24^{\mathrm{a}}$ & $11260^{\mathrm{b}}$ & $20065^{\mathrm{b}}$ & $56.24^{\mathrm{a}}$ \\
\hline $\mathbf{H}_{\mathbf{1}}(\mathbf{c o n t r o l})$ & $317.35^{\mathrm{b}}$ & $34.65^{\mathrm{a}}$ & $14.36^{\mathrm{a}}$ & $12140^{\mathrm{a}}$ & $21005^{\mathrm{a}}$ & $58.19^{\mathrm{a}}$ \\
\hline $\mathbf{H}_{\mathbf{2}}$ & $339.25^{\mathrm{a}}$ & $29.5^{\mathrm{b}}$ & $14.8 \mathrm{~b}^{\mathrm{a}}$ & $10840^{\mathrm{c}}$ & $19680^{\mathrm{c}}$ & $55.37^{\mathrm{a}}$ \\
\hline $\mathbf{H}_{\mathbf{3}}$ & $340.95^{\mathrm{a}}$ & $31.98^{\mathrm{ab}}$ & $13.79^{\mathrm{a}}$ & $11070^{\mathrm{b}}$ & $19710^{\mathrm{b}}$ & $56.77^{\mathrm{a}}$ \\
\hline
\end{tabular}

Results are mean of four replicates; Means in each column followed by similar letter (s) are not significantly different at 5\% probability level using Dancan's Test; F1 (100\% chemical fertilizers); F2 (100\% Biological and 75\% chemical fertilizers); F3 (100\% Biological and $50 \%$ chemical fertilizers); F4 (100\% Biological and 25\% chemical fertilizers); H1 (Single cross 704); H2 (Single cross Mobin); H3 (Single cross 701) 
Table 4 Effect of combined application of chemical and biofertilizers on various growth parameters of the corn plants.

\begin{tabular}{|c|c|c|c|c|c|c|}
\hline Treatments & $\begin{array}{c}1000 \text { - grain } \\
\text { weight (g) }\end{array}$ & $\begin{array}{c}\text { Number of } \\
\text { grains per row }\end{array}$ & $\begin{array}{l}\text { Number of } \\
\text { rowsper ear }\end{array}$ & $\begin{array}{c}\text { Grainyield } \\
\left(\text { kgha-1 }^{-1}\right)\end{array}$ & $\begin{array}{c}\text { Biological yield } \\
\left(\text { kgha-1 }^{-1}\right)\end{array}$ & $\begin{array}{c}\text { Harvest index } \\
(\%)\end{array}$ \\
\hline $\mathrm{H}_{1} \mathrm{~F}_{1}$ (control) & $307.00^{\mathrm{f}}$ & $36.60^{\mathrm{a}}$ & $14.10^{\text {cd }}$ & $11580^{\mathrm{e}}$ & $19860^{\mathrm{g}}$ & $58.74^{\mathrm{ab}}$ \\
\hline $\mathbf{H}_{2} \mathbf{F}_{1}$ & $346.00^{\mathrm{a}}$ & $29.14^{\text {cd }}$ & $14.99^{\mathrm{ab}}$ & $11105^{\mathrm{g}}$ & $19480^{\mathrm{i}}$ & $57.42^{\mathrm{b}}$ \\
\hline $\mathrm{H}_{3} \mathrm{~F}_{1}$ & $341.05^{\mathrm{b}}$ & $32.63^{\mathrm{b}}$ & $13.51^{\mathrm{e}}$ & $10990^{\mathrm{i}}$ & $19510^{\mathrm{h}}$ & $56.64^{\mathrm{bc}}$ \\
\hline $\mathbf{H}_{1} \mathbf{F}_{2}$ & $310.85^{\mathrm{f}}$ & $35.68^{\mathrm{a}}$ & $14.46^{\mathrm{c}}$ & $11820^{\mathrm{c}}$ & $21220^{\mathrm{b}}$ & $56.31^{\mathrm{bc}}$ \\
\hline $\mathbf{H}_{2} \mathbf{F}_{2}$ & $335.40^{\mathrm{c}}$ & $30.49^{c}$ & $14.00^{\text {cd }}$ & $10870^{\mathrm{j}}$ & $19005^{1}$ & $57.25^{\mathrm{b}}$ \\
\hline $\mathrm{H}_{3} \mathbf{F}_{2}$ & $341.85^{\mathrm{b}}$ & $32.21^{\mathrm{b}}$ & $13.72^{\mathrm{de}}$ & $11100^{\mathrm{h}}$ & $19030^{\mathrm{k}}$ & $58.95^{\mathrm{ab}}$ \\
\hline $\mathrm{H}_{1} \mathbf{F}_{3}$ & $321.55^{\mathrm{e}}$ & $36.34^{\mathrm{a}}$ & $14.00^{\mathrm{cd}}$ & $12385^{\mathrm{b}}$ & $21860^{\mathrm{a}}$ & $57.56^{\mathrm{ab}}$ \\
\hline $\mathbf{H}_{2} \mathbf{F}_{3}$ & $341.85^{\mathrm{b}}$ & $30.10^{c}$ & $15.11^{\mathrm{a}}$ & $11205^{\mathrm{f}}$ & $20300^{\mathrm{e}}$ & $55.57^{\mathrm{c}}$ \\
\hline $\mathbf{H}_{3} \mathbf{F}_{3}$ & $346.15^{\mathrm{a}}$ & $32.01^{\mathrm{b}}$ & $14.04^{\text {cd }}$ & $11585^{\mathrm{d}}$ & $21055^{\mathrm{d}}$ & $55.39^{c}$ \\
\hline$\overline{H_{1} F_{4}}$ & $327.40^{\mathrm{d}}$ & $37.50^{\mathrm{a}}$ & $14.23^{\mathrm{c}}$ & $12875^{\mathrm{a}}$ & $21180^{\mathrm{c}}$ & $60.5^{\mathrm{a}}$ \\
\hline $\mathrm{H}_{2} \mathbf{F}_{4}$ & $333.65^{\mathrm{c}}$ & $28.25^{\mathrm{d}}$ & $14.68^{\mathrm{b}}$ & $10215^{1}$ & $19935^{\mathrm{f}}$ & $51.21^{\mathrm{d}}$ \\
\hline $\mathbf{H}_{3} \mathbf{F}_{4}$ & $337.05^{\mathrm{c}}$ & $31.26^{\mathrm{b}}$ & $13.80^{\mathrm{d}}$ & $10680^{\mathrm{k}}$ & $19085^{\mathrm{j}}$ & $57.01^{\mathrm{b}}$ \\
\hline
\end{tabular}

Results are mean of four replicates; Means in each column followed by similar letter (s) are not significantly different at $5 \%$ probability level using Dancan's Test; F1 (100\% chemical fertilizers); F2 (100\% Biological and 75\% chemical fertilizers); F3 (100\% Biological and 50\% chemical fertilizers); F4 (100\% Biological and 25\% chemical fertilizers); H1 (Single cross 704); H2 (Single cross Mobin); H3 (Single cross 701)

\subsection{Weight of 1000-grain (gr)}

Based on the results of study, in terms of the 1000-grain weight, a significant difference was reported at the $1 \%$ level. The difference for the combination of biological fertilizer with grain weight was not significant (table2). The hybrid effect on grain weight was significant at the $1 \%$ level (table3) given that they were in a statistical range, but the Karun single cross hybrids had the highest amount of 340.95gr.The highest 1000 grain weight (336.55 gr) was recorded (table 2) for the combination of $50 \%$ chemical fertilizer with $100 \%$ biological fertilizer and single cross 701(Karun) with 50\% integrated fertilization as the amount of $346.15 \mathrm{gr}$, which was the second highest treatment. In addition, Dhillon et al. (1980) and Gholami et al. (1999) reported an increase in seed weight in the presence of biological fertilizer. Research has also reported an increase in the grain weight of corn from an application of biological fertilizer (Mohammed et al., 2001).

\subsection{Number of Grains per Row}

The number of grains is an important yield contributing trait that can greatly affect the economic return. Based on the results of testing number of kernels per row, there is a significant difference at the $1 \%$ level (table2). The difference for the combination of biological fertilizer on the number of grains per row was not significant. The hybrid impact on the number of kernels per row has significant effect at the $1 \%$ level (table 3), so that the single cross 704 had the highest number (36.45) and the Mobin hybrid had the lowest number (29.5) of kernels per row. According to table 4, the highest number of kernels per row belonged to hybrid 704 with the $25 \%$ chemical fertilizer and biological fertilizer (37.50) and the minimum (28.25) number of grains per row was recorded in the $25 \%$ chemical fertilizer with $100 \%$ biological fertilizer and single cross Mobin. From previous results it can be observed that the use of growth stimulating bacteria and supplement chemical fertilizer could increase the ear weight, number of rows, and number of seeds per row in corn (Yazdani et al., 2009). Seed inoculation with Rhizobium bacteria, phosphate solubilizing bacteria, and organic modification increased the production of seed crops (Panwar et al., 2006).

\subsection{Number of Rows per Ear}

The results of the ANOVA from table 2 revealed that only tested hybrids at the $1 \%$ significant level had an effect on the number of rows per ear (table 1) and the other main effects and interactions on the number of kernel rows per ear was notsignificant. According to table 3, highest number of rows, with 14.36, belonged to the hybrid (Single cross 704). According to the results presented in table 4 the hybrid combination of 50\% chemical fertilizer and biological fertilizer had 15.11 and the hybrid with $100 \%$ chemical fertilizer had 14.99 tows per ear and it was the highest, while the Karun treatment with100\% chemical fertilizer had the lowest value of 13.51 for the number of kernel rows per ear. Hamidi et al. (2007) and Nassiri Rad et al. (2011) increased the number of rows per ear of corn with seed inoculation by Azotobacter and Azospirillum species.

\subsection{Biological Yield (kgha-1)}

Based on the results of the two years of testing in terms of the biological yield at the $1 \%$ level, a significant difference was reported among various traits (table 2).The difference for the combination of biological fertilizer on the biological yield was significant at the $5 \%$ level. As shown in table 3,50\% chemical fertilizer with biological fertilizer gave $21,075 \mathrm{~kg} / \mathrm{ha}$ biological yield and it was the highest while $100 \%$ chemical fertilizer 
alone gave an amount of $19,580 \mathrm{~kg} / \mathrm{ha}$ as the lowest yield. The hybrid effect on the yield was significant at the 5\% level; as shown in table 3 single cross 704 had a value of $21,005 \mathrm{~kg} / \mathrm{ha}$ as the highest and the Mobin hybrid with the amount of 19,680 $\mathrm{kg} / \mathrm{ha}$ was the lowest yield. According to the analysis of the variance, there was no significant interaction between the fertilizer and hybrid traits, but according to the results in table 4 the largest treatment belonged to the hybrid 704, with 50\% chemical fertilizer with the biological fertilizer and the amount of $21,860 \mathrm{~kg} / \mathrm{ha}$. These findings are similar to those reported by Ullah et al. (2008) and Enan (2009).

3.6 Harvest Index (\%)

The physiological ability of a hybrid to convert total dry matter in to grain yield is determined by its harvest index (HI). The data (table 2) revealed that a significant effect on the harvest index was observed among the hybrids and interaction treatments, but there was no significant affect among the fertilization treatments. According to table 3, the single cross 704 had the highest harvest index of 58.19.

\section{Conclusion}

Results of this study indicated that various treatments have significant effect on the grain yield and yield components. According to the results bacteria have positive role in the production of bio-fertilizers and hormones which play a significant role in regulating plant growth while mixing them with chemical fertilizers as a supplement the level and depth of the roots. This combination also increases the rate of water and nutrient absorbance which raise the rate of growth and photosynthesis. These combination also increase the grain yield, yield components, and biological function, it has been found that bio-fertilizers can be combined with chemical fertilizers in a complementary way to reduce the excessive amount of chemical fertilizers used to grow corn. It was shown that the mixing of biological fertilizers with chemical fertilizers could reduce the needs of chemical fertilizers upto $25 \%$ and these results are comparable to the application of $100 \%$ chemical fertilizers. Therefore, the best hybrid maze is the single cross 704 that has good yield potential when the chemical fertilizer is used at either $25 \%$ or $50 \%$ of the current application when mixed with the bio-fertilizer.

\section{Conflict of interest}

Authors would hereby like to declare that there is no conflict of interests that could possibly arise.

\section{References}

Balasubramaniyan P, Palaniappan SP (2001)Nutrient management. In: Principles and practices of agronomy. Agrobios, India. 185- 188.

Biari A, Gholami A, Rahmani HA (2008) Growth promotion and enhanced nutrient uptake of maize by application of plant growth promoting rhizobacteria in arid region of Iran. Journal of Biological Sciences 8:1015-1020. DOI: 10.3923/jbs.2008.1015.1020.

Boddey RM, Dobereiner J (1988) Nitrogen fixation association with grasses and cereals: Recent results and perspective for future research. Plant and Soil 108: 53-65. DOI: 10.1007/BF02370099.

Bundy LG, Carter PR (1988) Corn hybrid response to nitrogen fertilization in northern Corn Belt. Journal of Production Agriculture $1: 99-104$.

Chen J (2006) The combined use of chemical and organic fertilizers and/or bio-fertilizer for crop growth and soil fertility. International Workshop on Sustained Management of the Soil Rhizosphere System for Efficient Crop Production and Fertilizer Use held on 16-20 October, 2006 at Thailand Pp. 11.

Delate K, Camberdella CA (2004) Agro-ecosystem performance during transition to certified organic grain production. Agronomy Journal 96: 1288-1298. doi:10.2134/agronj2004.1288.

Dhillon G, Kler GS, Walia AS, Chahal VPS (1980) Effect of Azotobacterchroococcumand seed size on growth and yield of maize. India Journal of Agronomy 25:244-2490

El-Douby KA, Ali EA, Toaima SEA (2001) Effect of nitrogen fertilizer defoliation and plant density on maize grain yield. Egypt Journal of Agricultural Research., 79: 965-981.

El-Kholy MA, El-Ashry S, Gomaa AM(2005)Biofertilization of Maize Crop and its Impact on Yield and Grains Nutrient Content under Low rats of Mineral Fertilizers. Journal of Applied Sciences Research 1: 117-121.

Enan MR (2009) Genotoxicity of the herbicide 2, 4dichlorophenoxyacetic acid (2, 4-D): Higher plants as monitoring systems, American-Eurasian Journal of Sustainable Agriculture 3: 452-459

Gholami A, Kochaki A, Mazaheri D, Ghalavand A (1999) Assessment effect of different strain Micorhiza on growth maize Iran. Crop Science Journal 3:45-47.

Hamidi A, Ghalavand A, DehghanShoar M, Malakuti MJ, Asgharzadeh A, Chokan R (2007) The effects of application of plant growth promoting rhizobacteria (PGPR) on the yield of fodder maize (Zea mays L.) Pajouhesh \& Sazandegi 70: 16-22.

Kizilkaya R (2008) Yield response and nitrogen concentration of spring wheat inoculated with Azotobacter chroococcum strains. Ecological Engineering 33:150-156.

Kusaksiz T (2010) Adaptability of some new maize (Zea mays L.) cultivars for silage production as main crop in 
Mediterranean environment. Turkish Journal of Field Crops 15 : 193-197.

Ladha KJ, Pathak H, Krupnik TJ, Six J, van Kessel C (2005) Efficiency of fertilizer nitrogen in cereal production: Retrospects and prospects. Advances in Agronomy 87: 85-156. doi:10.1016/S0065-2113(05)87003-8.

Mohammed AS, AbdelMonem MA, Khalifa HE, Beider M, ElGhandour IA, Galal YGM (2001) Using biofertilizers for maize production : response and economic return under different irrigation treatments. Journal of Sustainable Agriculture 19:41-48.

Naserirad H, Soleymanifard A, Naseri R (2011) Effect of integrated application of bio-fertilizer on grain yield, yield components and associated traits of maize cultivars. AmericanEurasian Journal of Agricultural and Environmental Science 10 : 271-277.

Panwar AS, Singh NP, Saxena DC, Hazarika UK (2006) Yield and quality of groundnut seed as influence by phosphorus, biofertilizer and organic manures. Indian Journal of Hill Farming 15:68-71.

Rahmany H, Nouraki F (2015) Effect of replacing Nicosulfuron and Foramsulfuron plus Cultivation instead of Atrazin and Alachlor in Maize (S.c.704) in the North of Khuzestan in Iran. International Journal of Agriculture and Crop Sciences $8:$ 302-306.

Scharf PC, Wiebold WJ, Lory JA (2002) Corn yield response to nitrogen fertilizer timing and deficiency level. Agronomy Journal 94 : 435-441.DOI: 10.2134/agronj2002.0435
Shevananda ( 2008) Influence of bio-fertilizers on the availability of nutrients $(\mathrm{N}, \mathrm{P}$ and $\mathrm{K})$ in soil in relation to growth and yield of Stevia rebaudiana grown in South India. International Journal of Applied Research in Natural Products 1: $20-24$.

Singh DK, Pandey AK, Pandey UB, Bhonde SR (2002) Effect of Farmyard Manure Combined with Foliar Application of NPK Mixture and Micronutrients on Growth, Yield and Quality of Onion. Newsletter-National Horticultural Research and Development Foundation 21-22 :1-7.

Szulc P ( 2013) Effects of soil supplementation with urea and magnesium on nitrogen uptake, and utilization by two different forms of maize (Zea mays L.) differing in senescence rates. Polish Journal of Environmental Studies 22 : 239 -248.

Ullah W, Khan MA, Arifullah SH, Sadiq M (2008) Evaluation of integrated weed management practices for maize. Pakistan Journal of Weed Sciences Research14: 19-32.

Yazdani M, Bahmanyar MA, Pirdashti H, Esmaili MA (2009) Effect of phosphate solubilization microorganisms and plant growth promoting rhizobacteria on yield and yield components of corn. International Journal of Biological and Life Sciences 1: $2-6$

Zeidan MS, Amany A, Bahr-El- Kramany MF (2006)Effect of Nfertilizer and plant density on yield and quality of maize in sandy soil. Research Journal of Agriculture and Biological Sciences 2: 156-161.

Zeid IM (2008) Effect of arginine and urea on polyamines content and growth of bean under salinity stress. Acta Physiologiea Plantarum 28: 44-49 